\title{
Risk Regulation for the Legal Profession
}

\author{
ADAM DODEK $^{*}$ AND EMILY ALDERSON ${ }^{* *}$
}

This article explores the current state of Canadian legal services regulation and changes that are impacting it. The authors argue that the only legitimate purpose for legal services regulation is the protection of the public interest, and this goal is best achieved through risk regulation. The article discusses four roles risk plays in regulation: as an object of, and justification for, regulation, as an organizing principle, and as a measure of accountability. It includes practical examples and comparisons to other jurisdictions and professions. Finally, the authors recognize that substantial changes will be required to shift to a risk regulation regime for legal services, but that such a change is necessary.

\section{TABLE OF CONTENTS}

\section{INTROduction: The Challenge of Legal SeRVicES}

REgUlation In CANADA. . . . . . . . . . . . . . . . 622

II. THE CASE FOR Risk REgUlation. . . . . . . . . . . . . . . . . . . . . 624

A. Defining Risk Regulation. . . . . . . . . . . . . . . . . . 624

B. DefinING THE GOAL. . . . . . . . . . . . . . . . . . . . . 625

C. InAdequacies in the PREVAiling APPROACH to

LEGAL SERVICES REGULATION IN CANADA. . . . . . . . . . . . . 628

III. How It Is DONE: Risk REGULATION IN ACTION.. . . . . . . . . . . . . 631

A. RISK IDENTIFICATION: ORGANIZATIONAL OBJECTIVES

AND ASSOCIATED RISKS.. . . . . . . . . . . . . . . . . 632

B. Risk Assessment: Collect AND Process Data. . . . . . . . . . . . 634

C. Risk MANAGEMENT: INTERVENE ACCORDINGLY. . . . . . . . . . . . . . 640

D. RISK COMMUNICATION:

SHARE INFORMATION WHERE NECESSARY. . . . . . . . . . . . . . . . 641

E. EVAluAtion, FeEDBACK, AND

MODIFICATION OF RISK CYCLE. . . . . . . . . . . . . . . . 642

IV. CONCLUSION. . . . . . . . . . . . . . . . . . . . . . . . . . . . . 643

** $\quad$ Faculty of Law, University of Ottawa. Member of the Public Law Group.

Legal Counsel, Department of Justice Canada. The views expressed in this article are the authors' own and in no way represent the position of the Government of Canada or the Department of Justice. Thanks to Richard Devlin, Amy Salyzyn, and several anonymous reviewers for reading earlier drafts and providing helpful comments on this article. We were greatly assisted in our work by the generosity of numerous people. Victoria Rees and Darrell Pink of the Nova Scotia Barristers Society (NSBS) explained to us the reforms being made at the NSBS, shared materials with us, and made introductions for us with the Solicitors Regulatory Authority (SRA). Andrew Garbutt, former Director of Risk at the SRA answered all of our questions in great detail and shared materials with us. Frederica Wilson of the Federation of Law Societies of Canada graciously shared presentations with us that led us down the path of considering the regulation of doctors and of securities. Many others assisted us and we are grateful to Kristin Dangerfield, CEO of the Law Society of Manitoba; Deborah Armour, Chief Legal Officer, Law Society of British Columbia; Felicia Ciolfitto, Manager, Trust Regulation Group, Law Society of British Columbia; Cori Ghitter, Director, Professionalism and Policy, Law Society of Alberta; Dr. Galt Wilson, Associate Registrar, College of Physicians of Surgeons of British Columbia; Amy Block, Legal Counsel, College of Physicians and Surgeons of Ontario; Bryan Salte, Registrar, College of Physicians and Surgeons of Saskatchewan; Erez Blumberger, Chief Regulatory Counsel, AUM Law (former Deputy Director and Acting Director, Compliance and Registration, Ontario Securities Commission); Warren Funt, Vice-President, Western Canada, IIROC; Christine Wolf, Chief Economist, B.C. Securities Commission; Elizabeth Silcox, Real Estate Council of Ontario; and Jim Milne, Acting Commissioner, NSW Office of the Legal Services Commissioner. 
Legal regulation needs "a scalpel, not a broad-sword"

\section{Michael Trebilcock $(2001)^{1}$}

\section{INTRODUCTION: \\ The Challenge of Legal Services Regulation in Canada}

The winds of change are blowing over the Canadian legal profession. The last decade has witnessed many developments at the national level including a uniform national code of conduct for common law jurisdictions and the Federation of Law Societies of Canada's National Mobility Agreement. In Ontario, paralegals are now regulated and articling can be done through the Law Practice Program. The new law school at Lakehead University in Thunder Bay, Ontario, has implemented a curriculum so practical, their graduates are not required to article. Ryerson University in Toronto has announced that it too plans on opening a new law school with a more practical approach to professional pedagogy. ${ }^{2}$

Deeper changes are also in the works. Spurred on by the Canadian Bar Association's (CBA) Legal Futures Project, there has been much introspection in the profession about how and why we regulate lawyers. Several law societies are considering entity regulation and alternative business structures, in line with the CBA's recommendations. The increasing pace of change caused the Law Society of Ontario's former Treasurer Thomas Conway to remark in 2013 that more changes had occurred in the regulation of the legal profession over the past 20 years than in the previous $200 .{ }^{3}$ Conway was not exaggerating.

Despite these changes, legal services regulation ${ }^{4}$ remains very much a laggard compared to the regulation of other professions and other industries. For the most part, legal services regulation remains rigid, reactive, and complaint-based. These are not characteristics that are considered regulatory best practices. Recognizing this, a number of law societies are contemplating more proactive, compliance-based regulation. ${ }^{5}$ Indeed, some Canadian legal

Michael Trebilcock, "Regulating Legal Competence" (2001) 34:3 Can Bus LJ 444 at 459 [Trebilock, "Regulating Competence"].

2 Trinity Western University has sought approval from the British Columbia government and accreditation from provincial law societies to open a law faculty. That process is the subject of ongoing debate and litigation. See Diane Mehta, "Private Christian University Trinity Western Takes Fight to Top Courts," Globe and Mail (5 June 2016), online: <www.theglobeandmail.com/news/national/education/privatechristian-university-trinity-western-takes-fight-to-top-courts/article30282287/>. See also Trinity Western University $v$ Law Society of Upper Canada, 2016 ONCA 518, 131 OR (3d) 113; The Nova Scotia Barristers' Society v Trinity Western University, 2016 NSCA 59, 376 NSR (2d) 1; Trinity Western University $v$ The Law Society of British Columbia, 2015 BCSC 2326, 392 DLR (4th) 722. 3 Thomas G Conway, "Remarks at the Cavanagh LLP Professionalism Lecture Series" (delivered at the

4 We adopt Noel Semple's definition of legal services regulation as consisting of "rules about who can provide legal services, what characteristics those services must possess, and under what conditions they can be provided" (Noel Semple, Legal Services Regulation at the Crossroads: Justitia's Legions (Cheltenham, UK: Edward Elgar, 2015) at 13).

5 See e.g. The Law Society of Alberta, The Law Society of Saskatchewan \& The Law Society of Manitoba, Innovating Regulation: A Collaboration of the Prairie Law Societies (November 2015), online: <www.lawsociety.sk.ca/media/127107/INNOVATINGREGULATION.pdf> [Law Societies, Innovating Regulation]; Nova Scotia Barristers' Society, "Framework for Legal Services Regulation," online: <www.nsbs.org/framework-legal-services-regulation> [NSBS Framework]; Law Society of British Columbia, "2015-2017 Strategic Plan," online: <https://www.lawsociety.bc.ca/docs/about/ StrategicPlan_2015-17.pdf $>$; Law Society of Ontario, Compliance-Based Entity Regulation Task Force, Report to Convocation (26 May 2016), online: <www.lsuc.on.ca/uploadedFiles/For_the_Public/ About_the_Law_Society/Convocation_Decisions/2016/convocation_may_2016_cber.pdf $\$$. 
regulators have already turned those thoughts into action, most notably the Nova Scotia Barristers' Society ${ }^{6}$ and the Law Society of Alberta. ${ }^{7}$ We assert that Canadian legal regulators should continue down this path and move to risk regulation, a more focused and efficient system of regulation. This is a positive development and should be embraced by all Canadian law societies.

Other scholars have addressed the continuing viability of self-regulation for the legal profession in Canada. ${ }^{8}$ It is not our mandate to tackle that issue here. In fact, we are agnostic about self-regulation for the purposes of our argument. Our focus is not on who should regulate legal professionals but on how they should be regulated.

We assert that the only legitimate normative basis for regulation of the legal profession - whether that continues to be self-regulation or some other form of regulation as exists in other jurisdictions - is the protection of the public interest. This should not be a particularly controversial proposition; it is part of the standard justification for self-regulation of the legal profession. ${ }^{9}$ However, much of the criticism of self-regulation relates to the failure of the legal profession to live up to this standard, or the profession's pursuit of its own interests. We believe that risk regulation provides a better, more targeted way for law societies to fulfil their mandates to regulate legal services in the public interest. ${ }^{10}$

Our article has four parts including this introduction. Part II sets out the normative case for risk regulation. We begin by explaining the four different roles that risk plays in regulation: as an object of regulation; as a justification for regulation; as an organizing principle for operations; and as a measure of accountability. This part addresses the first two aspects of risk regulation and identifies deficiencies in current approaches to legal regulation in Canada. We then explain why risk regulation would be an improvement in legal regulation. In Part III we address the third aspect of risk regulation, using practical examples to illustrate how risk regulation is actually done. In doing so, we draw on examples from the regulation of lawyers in other jurisdictions, specifically England and Wales and Australia. We also draw upon examples from the regulation of medicine and finance in Canada. In Part IV, our article ends with a brief conclusion in which we recognize that significant cultural and operational changes are required to move to a risk regulation regime.

The Law Society of Alberta has an "Early Intervention Intake System" in which incoming information (such as complaints) is triaged. Each matter is assessed and can be sent to informal resolution, early intervention programming for the lawyer, or discipline. The Law Society is also working on a draft selfassessment tool. Emails from Cori Ghitter, Director, Professionalism and Policy, Law Society of Alberta (31 October 2016 and 9 November 2016) [on file with authors].

$8 \quad$ See most notably HW Arthurs, "The Dead Parrot: Does Professional Self-Regulation Exhibit Vital Signs?" (1995) 33:4 Alta L Rev 800 [Arthurs, "Dead Parrot"]; Richard F Devlin \& Porter Heffernan, "The End(s) of Self-Regulation?" (2008) 45:5 Alta L Rev 169.

9 See Alice Woolley et al, Lawyers' Ethics and Professional Regulation, 2nd ed (Toronto: Lexis Nexis, 2012) ("[s]elf regulation is undertaken in the public interest to ensure that legal services are provided to the public ethically and competently by only those persons qualified to do so" at 67).

10 We recognize that others have advocated risk regulation for legal services. See e.g. Semple, supra note 4 at 245-48. 


\section{The CASE FOR RiSk REgUlation}

\section{A. Defining Risk Regulation}

Regulatory approaches have changed significantly over the past several decades but legal regulation in Canada has not kept pace. The meaning of "regulation" has become dynamic. Traditionally, regulation was conceived of as external "command and control" by government. ${ }^{11}$ However, this conception of regulation is now considered both outdated and problematic. ${ }^{12}$ The Oxford Handbook of Regulation defines regulation as "the intentional use of authority to affect behaviour of a different party according to set standards, involving instruments of information gathering and behavior modification." 13 Scholars and public policy makers have argued for deregulation, "responsive regulation," "smart regulation," 15 and "problem-centred regulation." 16 These theories or models of regulation have in turn been subject to criticism and challenged by alternatives such as "principles-based" and "riskbased" approaches to regulation. ${ }^{17}$

"Risk regulation," also called "risk-based regulation," is an outgrowth of the "better regulation" movement which seeks to improve regulation through a number of coordinated or linked strategies. ${ }^{18}$

"Risk" can play an important role in different parts of the regulatory process. Julia Black has written that risk presently plays "four main roles in regulation: providing an object of regulation; justifying regulation; constituting and framing regulatory organisations and regulatory procedures; and framing accountability relationships." ${ }^{19}$ Black explains as follows:

Risk is an object of regulation in that much regulatory activity is defined in terms of risk. Risk plays a justificatory role in that it defines the object and purpose of, and provides justification for, regulation, and thus frames regulatory policy making. Risk plays an organisational and procedural role in that risk provides the basis for the regulator to operationalise its objectives and for the introduction of particular sets of internal organisational policies and processes. Risk provides an internal and external evaluative and accountability role in that the language of risk is used, both within the organisation and by those outside it, to define a matrix of measures which are used in an attempt to structure the discretion of the organisation and those working within it, to make them accountable, and to provide a (contested) criterion of evaluation. ${ }^{20}$

Cf Robert Baldwin, Martin Cave \& Martin Lodge, "Introduction: Regulation - The Field and the Developing Agenda" in Robert Baldwin, Marvin Cave \& Martin Lodge, eds, The Oxford Handbook of Regulation (Oxford: Oxford University Press, 2010) 1 at 5 [Baldwin, Cave \& Lodge, "Regulation"]. Ibid at 12 citing Philip Selznick, "Focusing Organizational Research on Regulation" in Roger G Noll, ed, Regulatory Policy and the Social Sciences (Berkeley: University of California Press, 1985) 363. Baldwin, Cave \& Lodge, "Regulation," ibid at 12.

See e.g. Ian Ayres \& John Braithwaite, Responsive Regulation: Transcending the Deregulation Debate (Oxford: Oxford University Press, 1992).

Neil Gunningham \& Peter Grabofsky, Smart Regulation: Designing Environmental Policy (Oxford: Oxford University Press, 1998).

Malcolm K Sparrow, The Regulatory Craft (Washington, DC: Brookings, 2000).

Baldwin, Cave \& Lodge, "Regulation," supra note 11 at 11.

Robert Baldwin, "Better Regulation: The Search and the Struggle" in Baldwin, Cave \& Lodge, ibid 259 at 267.

Julia Black, "The Role of Risk in Regulatory Processes" in Baldwin, Cave \& Lodge, ibid 302 at 303 [Black, "Role of Risk"].

Ibid at 303 [emphasis in original]. 
It is important to keep these four different meanings or applications of risk in mind when evaluating how regulators use risk in their regulatory processes. A regulator may embrace risk in each of these four regulatory aspects or use risk in a more limited way.

In this article, we are concerned with risk in all four interconnected meanings.

The starting point for any analysis of risk regulation is defining "risk." Black defines risk generally as "the possibility that something undesirable will occur, whether as a result of natural events or human activities, or some combination of the two. ${ }^{21}$ Risk regulation, as the name implies, seeks to control risk. Thus it requires a very clear definition of the desired outcomes in order to identify the risks that threaten those outcomes. ${ }^{22}$ In legal regulation, the risk of harm to the public serves as the object of regulation - this risk is what the regulator seeks to control.

Risk regulation therefore forces the regulator to justify their goals and the actions they take to meet them. This is obviously a dynamic process. Goals will change over time and will be contested by the regulated population. This step in the process also plays a valuable role in norm creation and articulation.

At the practical level, the regulator must design operations and procedures to meet the risk-reduction goals they have put forward. This keeps their whole operation results-focused and draws attention to big risks over small ones. The regulator can thus prioritize their resources on high risk actors and minimize the regulatory burden on low-risk actors. Ideally, more targeted regulation will also result in cost savings as resources are used more efficiently. In short, risk regulation allows regulators to focus their attention on issues that pose the greatest danger to their objectives. In turn, this enables regulators to make the most of their limited resources and better allocate their regulatory efforts. ${ }^{23}$

Finally, the clear goals articulated by the regulator also serve as a standard with which to evaluate their work and hold them accountable. The objectives and risks articulated in the first step of the risk cycle serve as measuring sticks to gauge performance. This is useful for the regulator to self-evaluate, and also for third parties to assess the regulator's activities. Regulated professionals and others can hold the regulator to account based on transparent and identifiable goals and objectives.

\section{B. DEFINING THE GOAL}

The starting point for risk regulation is thus objectives articulated in terms of risk - what risks does the regulator seek to control?

$21 \quad$ Ibid at 309, citing Anthony Giddens, The Consequences of Modernity (Stanford: Stanford University Press, 1990).

22 Baruch Fischhoff \& John Kadvany, Risk: A Very Short Introduction (Oxford: Oxford University Press, 2011) at 22 .

23 John Stevenson, Secretary of the Ontario Securities Commission, says that risk regulation has led to "better allocation of our regulatory efforts" for his organization (John Stevenson, "The Regulatory Craft: Challenges in Regulation in the Twenty-First Century" (Remarks to Federation of Law Societies Council Meeting, April 2014) at 00h:08:00s-00h:10m:00s [unpublished]). 
In Canada today, the public interest is the purported objective of legal regulators from coast to coast. ${ }^{24}$ The Nova Scotia Barristers' Society undertook reforms with the aim of "transforming regulation and governance in the public interest, and enhancing access to justice." ${ }^{25}$ In British Columbia, it is "the object and duty of the society to uphold and protect the public interest in the administration of justice." ${ }^{26}$ In Quebec, the Office of the Professions safeguards that all professional regulators, including the Barreau de Québec, "ensure the protection of the public." 27 Likewise, in Ontario, the Law Society Act specifies that the regulator must, inter alia, "protect the public interest." ${ }^{28}$ The public interest remains the dominant objective of legal regulatory regimes outside of Canada as well. ${ }^{29}$

However, the idea of "public interest" is multifaceted and provides little practical guidance for regulators. There is no agreement on how to protect the public, nor what the public needs protection from. Indeed, there is not even consensus that regulation is needed to meet the public interest: Milton Friedman believed that exposing the profession to the full force of the market would be the most effective way to protect consumers. ${ }^{30}$ More recently, American author Benjamin Barton argued for deregulation of legal work done outside courts, saying it is unnecessary for consumer protection. ${ }^{31}$ Approaching the issue from a different perspective, Harry Arthurs believes lawyers' conduct is not strongly affected by regulation anyway. ${ }^{32}$

Others believe that while regulation can protect the public interest, current regimes are falling short of that goal. Deborah Rhode recommends that regulation be reformed to provide "less [protection] for attorneys and more for consumers." ${ }^{33}$ In 1992, David Wilkins noted the conflict of regulation theories and the lack of connection to enforcement regimes for American lawyers. ${ }^{34}$ In 2001, in writing about regulating legal competence in Canada, Trebilcock argued that law societies should shift their emphasis from regulating "inputs" to focus more on "outputs." He argued for "a more targeted, bottom-line, output-oriented

Russell G Pearce, Noel Semple \& Renee Newman Knake, “A Taxonomy of Lawyer Regulation: How Contrasting Theories of Regulation Explain the Divergent Regulatory Regimes in Australia, England/ Wales, and North America" (2013) 16:2 Leg Ethics 258 at 260.

25 Victoria Rees, Transforming Regulation and Governance in the Public Interest (15 October 2013) at 4, online: $<$ https://nsbs.org/sites/default/files/cms/news/2013-10-30transformingregulation.pdf $>$ [Rees, Transforming Regulation].

Legal Profession Act, SBC 1998, c 9, s 3

Professional Code, CQLR c C-26, s 12.

Law Society Act, RO 1990, c L.8, s 4.2 .

In England and Wales, the very first line of the SRA handbook reads "Consumer interests and the general public interest are the key justifications for any regulatory scheme" (Solicitors Regulation Authority, SRA Handbook (2017), online: <www.sra.org.uk/solicitors/handbook/intro/content.page>). We acknowledge that some law societies in Canada still identify the interest of their members or of the profession as a regulatory objective. See e.g. Legal Profession Act, RSA 2000, c L-8, s 49(1). For reasons that various authors have identified respecting other jurisdictions, the mixing of a public interest mandate with a representative function contributed to the loss of lawyer self-regulation in those jurisdictions. See especially Paul D Paton, "Between a Rock and a Hard Place: The Future of SelfRegulation - Canada Between the United States and the English/Australian Experience" [2008] J Professional Lawyer 87 . As we discuss below, to the extent that self-interest is implicitly or explicitly incorporated into law society regulatory objectives, it threatens regulatory focus and the regulatory legitimacy of law society regulation in Canada. See especially Milton Friedman, Capitalism and Freedom (Chicago: University of Chicago Press, 1962) ch 9.

Benjamin Hoorn Barton, "Why Do We Regulate Lawyers?: An Economic Analysis of the Justifications for Entry and Conduct Regulation" (2001) 33:2 Ariz St LJ 429.

Arthurs, "Dead Parrot," supra note 8.

Deborah L Rhode, Access to Justice (Oxford: Oxford University Press, 2004) at 90.

David B Wilkins, "Who Should Regulate Lawyers?" (1992) 105:4 Harv L Rev 799. 
regulatory focus, because that is what a consumer welfare perspective demands." ${ }^{35}$ The same year, Barton asserted that a disconnect existed between the public interest objective and the reality of regulation in the American legal profession. ${ }^{36} \mathrm{We}$ believe a similar disconnect between goals and outcomes exists today in Canada.

We acknowledge that the concept of public interest is contested. However, as a goal currently shared by all legal regulators, we take it as a starting point for our discussion of risk regulation. In order to put risk regulation into practice, however, each regulator would have to better define the public interest and articulate what risks to the public they wish to control. Expressly identified regulatory objectives are imperative. ${ }^{37}$ Canadian statutes governing the legal profession begin to do this but do not provide sufficient specificity. ${ }^{38}$

In framing the public interest, regulation would bring the contested process of norm articulation to the forefront. Much academic ink has been spilled in discussing the normative basis for (self) regulation, ${ }^{39}$ and the goals of legal regulation. ${ }^{40}$ Risk regulation would force

Trebilcock, "Regulating Competence," supra note 1 at 456. See also Michael Trebilcock, "Regulating the Market for Legal Services" (2008) 45:5 Alta L Rev 215 at 226 [Trebilcock, "Regulating the Market"].

36 Barton, supra note 31.

37 See generally Laurel S Terry, Steve Mark \& Tahlia Gordon, "Adopting Regulatory Objectives for the Legal Profession" (2012) 80:6 Fordham L Rev 2685 at 2687 (asserting at least four benefits to adopting regulatory objectives: (1) articulating the purpose of lawyer regulation and its parameters; (2) identifying the purpose of regulation and its parameters for those affected by lawyer regulation; (3) assisting in ensuring that the function and purpose of the particular legislation is transparent; and (4) assisting the legal profession in negotiating with governmental and nongovernmental entities about regulations affecting legal practice).

38 For a review of regulatory objectives in Canadian statutes governing the legal profession see ibid at 2753-58. South of the border, in February 2016, the American Bar Association adopted the "ABA Model Regulatory Objectives for the Provision of Legal Services," online: <https://www.americanbar. org/content/dam/aba/events/professional_responsibility/2017\%20Meetings/2017upl_school/Material s/closingplenary/aba_model_regulatory_objectives.authcheckdam.pdf $>$. While these were adopted in the context of debate over the provision of "non-traditional" (i.e. non-lawyer) legal services they remain instructive. See Lorelai Laird, "ABA House approves model regulatory objectives for nontraditional legal services," ABA Journal (8 February 2016), online: <www.abajournal.com/news/article/house approves_proposed_model_regulatory_objectives_for_nontraditional_lega>. The ABA adopted the following ten regulatory objectives:

A. Protection of the public

B. Advancement of the administration of justice and the rule of law

C. Meaningful access to justice and information about the law, legal issues, and the civil and criminal justice systems

D. Transparency regarding the nature and scope of legal services to be provided, the credentials of those who provide them, and the availability of regulatory protections

E. Delivery of affordable and accessible legal services

F. Efficient, competent, and ethical delivery of legal services

G. Protection of privileged and confidential information

H. Independence of professional judgment

I. Accessible civil remedies for negligence and breach of other duties owed, disciplinary sanctions for misconduct, and advancement of appropriate preventive or wellness programs

J. Diversity and inclusion among legal services providers and freedom from discrimination for those receiving legal services and in the justice system.

Jethro K Lieberman, "Some Reflections on Self-Regulation" in Philip Slayton \& Michael J Trebilcock, eds, The Professions and Public Policy (Toronto: University of Toronto Press, 1978) 89 at 91.

We recognize that it is legitimate for legal regulators to have positive duties such as promoting access to justice, the rule of law, and diversity within the profession. There is a vast literature on these subjects. See e.g. Noel Semple, “Access to Justice: Is Legal Services Regulation Blocking the Path?” (2013) 20:3 Intl J Leg Profession 267; Jamie Baxter, Michael Trebilcock \& Albert Yoon, "The Ontario Civil Legal Needs Project: A Comparative Analysis of the 2009 Survey Data" in Michael Trebilcock, Tony Duggan \& Lorne Sossin, Middle Income Access to Justice (Toronto: University of Toronto Press, 2012); Canadian Bar Association, Reaching Equal Justice: An Invitation to Envision and Act (Ottawa: Canadian Bar Association, 2013), online: <www.cba.org/cba/equaljustice/secure_pdf/Equal-Justice-Reporteng.pdf>; Law Society of British Columba, "Towards a More Representative Legal Profession: Better 
regulators and the profession to engage more openly in the conversation as well. Each regulator will need to define their own goals and articulate what risks they seek to control.

In the abstract, risk regulation can be used to reach any goal that is framed in terms of risk reduction. Thus, it is possible that in addition to likely identifiable risks such as harm to the public and harm to clients, other risks such as risk to the reputation of the profession could also possibly be pursued simultaneously. ${ }^{41}$ However, for reasons that we identify below, we express grave skepticism about the propriety of the regulatory goal of protecting the reputation of the profession because we think it often competes with other objectives and there exists a natural tendency for lawyer-controlled bodies such as law societies to privilege protection of the profession over protection of clients and protection of the public. The benefit of risk regulation would be in requiring law societies to be explicit, and therefore transparent and accountable, in their rationale for protecting the standing of the legal profession.

\section{InAdequacies in the Prevailing APProach to LEgal SERVICES REgUlation IN CANADA}

The current approach to legal services regulation in Canada does not adequately meet the proclaimed purpose of protecting the public interest. There are several reasons for this. The first is the command and control approach to legal regulation in Canada which is characterized by its reactive, complaints-based approach. ${ }^{42}$ In a 2013 paper for the Nova Scotia Barristers' Society, Victoria Rees wrote that over the past 20 years, Canadian law societies have been moving away from command and control regulation because of "little or no evidence that it effectively protects the public." 43 Command and control regulation allows many cases of lawyer misbehaviour to slip through the cracks. It is based on the unrealistic expectation that clients will know the standards of lawyer competence, know their rights, and know when and where to complain - as well as have the motivation to do so. Complaints-based discipline also does not catch lawyer misbehaviour that benefits the client in question. ${ }^{44}$

Practices, Better Workplaces, and Better Results" (British Columbia: Law Society of British Columbia, 2012); Lisa Vogt, "Gender Diversity: Preparing for the New Legal Environment” (2011) 44:1 UBC L Rev 55; Law Society of British Columbia, "The Business Case for Retaining and Advancing Women in Private Practice” (British Columbia: Law Society of British Columbia, 2009). These issues are generally beyond the scope of this article. However, there is no reason why risk regulation cannot be applied to the achievement of these positive objectives as well. That is, if access to justice is recognized as a regulatory objective then the "risk" is that access to justice is not being promoted.

41 The Law Societies of Alberta, the Northwest Territories, and Nunavut are empowered to regulate conduct that "tends to harm the standing of the legal profession generally." See Legal Profession Act, RSA 2000, c L-8, s 49(1)(b); Legal Profession Act, RSNWT 1998, c L-2, s 22; Legal Profession Act, RSNWT (Nu) 1988, c L-2, s 22(2)(b).

42 For criticisms of this reactive approach to legal regulation in Canada see Amy Salyzyn, "What if We Didn't Wait? Canadian Law Societies and the Promotion of Effective Ethical Infrastructure in Law Practices” (2013) 92:3 Can Bar Rev 507 [Salyzyn, "What if We Didn't Wait?"]; Trebilcock, "Regulating Competence," supra note 1; Trebilcock, "Regulating the Market," supra note 35; Adam M Dodek, "Regulating Law Firms in Canada" (2011) 90:2 Can Bar Rev 381 [Dodek, "Regulating Law Firms"]. Rees, Transforming Regulation, supra note 25 at 8.

$44 \quad$ Salyzyn, "What if We Didn't Wait?," supra note 42. 
The second reason for the inadequacy of the current system of legal regulation in Canada is that it has failed to provide sufficient focus on the content of the public interest. It has not facilitated a sufficiently demanding definition of the public interest that allows law society action to be measured against it. Put another way, the loose approach to the legal services regulation has led to law societies either mischaracterizing or losing sight of the public interest too frequently.

There are many examples, unfortunately, of law societies losing sight of the public interest. Historically, the power of self-regulation in Canada was utilized to prevent outsiders from entering the profession on various spurious grounds loosely connected to the assertion of "the public interest." 45 Many of the examples invoked by Richard Devlin and Porter Heffernan in their 2008 article as reasons "why Canadians might be concerned that the regulation of the legal system might not be working as well as one would want in a liberal democratic society" 46 can also be viewed through the lens of failure to protect the public interest. Their examples include failure to protect the public from incompetent lawyers, sexual relations with clients, exorbitant fees in the residential schools cases, and the failure to regulate fees. ${ }^{47}$ To these we would add several other examples.

Squelching dissent within the legal profession is not an effective pursuit of the public interest. ${ }^{48}$ In the 1960 s, the Barreau de Montréal sought to discipline Quebec Attorney General and Minister of Justice Claude Wagner (father of Supreme Court of Canada Justice Richard Wagner) for a speech that he gave in Drummondville in which he criticized the conduct of a judge. ${ }^{49}$ Perhaps most famously, the Barreau du Québec suspended lawyer Gilles Doré for two weeks for an intemperate letter that Doré wrote to a judge in a trial (who was himself the subject of a complaint to the Canadian Judicial Council). ${ }^{50}$ In recent years, there have been a number of high profile complaints lodged by lawyers against other lawyers for critical comments that they have made either about other lawyers or about controversial

$45 \quad$ See supra note 29.

$46 \quad$ Devlin \& Heffernan, supra note 8 at 172.

$47 \quad$ See ibid at $174-82$.

48 Devlin \& Heffernan note that independence of the bar is often used as a justification for self-regulation but they raise a number of instances where the bar has dramatically failed to stand up for dissenting views within Canadian society. See ibid at 193, citing Philip Girard, "The Independence of the Bar in Historical Perspective: Comforting Myths, Troubling Realities" in Law Society of Ontario, In the Public Interest: The Report and Research Papers of the Law Society of Upper Canada's Task Force on the Rule of Law and the Independence of the Bar (Toronto: Irwin Law, 2007) 45.

49 The Quebec Court of Appeal held that the Montreal Bar Council did not have jurisdiction over Minister Wagner because of immunity. See Barreau de Montréal c Wagner, [1968] BR 235. See also Adam Dodek, "Public Office and Standards of Conduct," CBA National (April-May 2013), online: <www. nationalmagazine.ca/Articles/Recent4/Public_office_and_standards_of_conduct.aspx $>$.

50 See Report of the Canadian Judicial Council to the Minister of Justice of Canada under ss 65(1) of the Judges Act concerning Mr. Justice Jean-Guy Boilard of the Superior Court of Quebec (19 December 2003), online: <www.cjc-ccm.gc.ca/cmslib/general/conduct_inq_boilard_ReportIC_200312_en.pdf>. 
public policy issues. ${ }^{51}$ This is not the place for us to debate the merits of law society prosecutions of Joe Groia, Gerry Laarakker, and others. Other writers have addressed this. ${ }^{52}$

The Doré v. Barreau du Québec case was appealed all the way to the Supreme Court of Canada, which unanimously affirmed law societies' power to sanction lawyers for intemperate criticism. ${ }^{53}$ Law societies continue to have rules of ethics which warn lawyers to avoid criticism of judges and tribunals. However, just because law societies have this power does not mean that they should be using it so aggressively. We believe that law societies' focus on civility, especially in the last 20 years, is problematic in two respects. First, because it is difficult to identify the harm to the public or to clients that such regulation intends to address. ${ }^{54}$ Second, and much more significant, is the opportunity cost involved in such prosecutions. ${ }^{55}$ Law societies' attention on civility distracts them from focusing on other behaviour that is arguably more harmful to clients or to the public. This is most certainly the case with the Law Society of British Columbia's prosecution of Gerry Laarakker and its complete failure to address the practice of abusive demand letters sent to parents of shoplifters. ${ }^{56}$

51 In one instance, a complaint was made to the Nova Scotia Barristers' Society against federal Minister of Justice Peter MacKay for comments that he made about Liberal leader Justin Trudeau and marijuana. The Nova Scotia Barristers' Society dismissed the complaint. See Paul McLeod, "Pot Complaint Against MacKay Dismissed," The Chronicle Herald (7 October 2013), online: <www.thechronicleherald.ca/ novascotia/1159162-pot-complaint-against-mackay-dismissed $>$. In another case, a complaint was made to the Law Society of Alberta against blogger Ezra Levant for controversial comments he made about public policy issues. Levant resigned from the Law Society before the hearing into his conduct was to commence. See "Ezra Levant Wins Right to Quit Law Society of Alberta and Have Complaints Annulled," National Post (2 March 2016), online: <nationalpost.com/news/canada/ezra-levant-winsright-to-quit-law-society-of-alberta-and-have-complaints-annulled $>$. In 2016, it was reported that former Ontario Ombudsman Andre Marin filed a complaint against pundit Warren Kinsella with the Law Society of Ontario. See Ashley Csanady, "Ontario's Former Ombudsman Filed Law Society Complaint Against Critical Pundit Before Leaving Office," National Post (17 February 2016), online: <national post.com/news/canada/ezra-levant-wins-right-to-quit-law-society-of-alberta-and-have-complaintsannulled>.

$52 \quad$ See especially Alice Woolley, "Does Civility Matter?" (2008) 46:1 Osgoode Hall LJ 175 [Woolley, "Does Civility Matter?”]; Alice C Woolley, “'Uncivil by Too Much Civility”?: Critiquing Five More Years of Civility Regulation in Canada" (2013) 36:1 Dal LJ 239; Micah Rankin, "Gerry Laarakker: From Rustic Rambo to Rebel with a Cause" in Adam Dodek \& Alice Woolley, eds, In Search of the Ethical Lawyer: Stories from the Canadian Legal Profession (Vancouver: UBC Press, 2016) 225. 2012 SCC 12, [2012] 1 SCR 395.

See Woolley, "Does Civility Matter?," supra note 52.

It is impossible to know exactly how much law societies spend on these prosecutions, in terms of budget or staff time. Some indication may be given by the fact that the Law Society of Ontario was awarded almost \$250,000 in costs at first instance in its prosecution of Joseph Groia before the Law Society Tribunal. This was reduced to $\$ 200,000$ by an appeal panel (Law Society of Upper Canada v Groia, 2014 ONLSTA 11, 2014 ONLSTA 11 (CanLII)). The Law Society of Ontario's largest segment of expenditures is "Professional Regulation, Tribunals and Compliance." Within this category, the biggest item is "typically spending on outside counsel and expert witnesses" (Law Society of Ontario, 2015 Financial Statements (2016) at 3, online: <www.annualreport.lsuc.on.ca/2015/en/financial-statements/ LSUC_2015_Financial_Statements.pdf $>$ ).

$56 \quad$ See Rankin, supra note 52; Amy Salyzyn, "Zealous Advocacy or Exploitative Shakedown? The Ethics of Shoplifting Civil Recovery Letters" (2015) 36 Windsor Rev Legal Soc Issues 1. On resources and opportunity cost, consider the controversial case of Ontario lawyer Joseph Groia, whose conduct in a case that started in the late 1990 s led to incivility proceedings in 2011 . The Law Society of Ontario has spent hundreds of thousands of dollars disciplining Groia and defending that discipline in the courts Groia was originally ordered to pay $\$ 250,000$ in costs at the disciplinary hearing alone. In a twist, Groia was elected a bencher of the Law Society in 2015 . He is now seeking leave to appeal to the Supreme Court, all the while sitting on the body that is fighting to uphold his incivility conviction. See Bruce Livesey, "The Trials of Joe Groia," The Globe and Mail (29 September 2011), online: <https://www.the globeandmail.com/report-on-business/rob-magazine/the-trials-of-joe-groia/ article596066/>; Jeff Gray, "Court Dismisses Bre-X Lawyer Joe Groia's Appeal Over Suspension," The Globe and Mail (2 February 2015), online: <https://www.theglobeandmail.com/report-on-business/industry-news/the-law-page/ court-dismisses-joe-groias-appeal-of-suspension/article22745513/>; Jacques Gallant, "'Rude’ Lawyer Joseph Groia Loses Appeal on Incivility Conviction," Toronto Star (14 June 2016), online: <https:// 
The current regulatory system has not always facilitated a clear focus on a public interest regulatory mission. It therefore becomes critical to identify the elements of the public interest because far too often law societies have defined the public interest in terms that coincide suspiciously with protection of the profession's interests and reputation. ${ }^{57}$ For the reasons set out in the previous section, risk regulation therefore should improve regulatory accountability.

Naysayers may assert that change is unnecessary and uncertain because there are no external pressures pushing regulatory reforms in Canada. This is an explanation for maintaining the status quo, not a normative justification of it. Moreover, as Devlin and Heffernan have argued, law societies have engaged in reforms in reaction to external pressures. ${ }^{58}$ The best argument for change comes from law societies themselves: over the past decade, most Canadian law societies have begun the process of considering serious changes to the way that they have always regulated legal services. That move should be applauded, supported, and expanded. Risk regulation provides a better structure for regulators to fulfill their mandate to protect the public interest. In the next section, we illustrate the basic mechanics of how regulators could put the theory of risk regulation into practice to more efficiently reach their shared goal of protecting the public interest.

\section{How It Is Done: Risk Regulation IN ACTION}

This section illustrates risk regulation in practice. Risk regulation is already being used by legal regulators in Australia and in England and Wales. In Canada, the Nova Scotia Barristers' Society is at the forefront of implementing such an approach. Risk regulation is commonly used in the financial sector and in medicine, both within Canada and internationally. Each regulatory body uses risk regulation differently and we draw upon examples that could be considered for application to legal regulation in Canada.

Despite differences between regulators, some commonalities can be identified. Most importantly, risk regulation is cyclical. Black's explanation of the multiple roles of risk within the regulatory process highlights this cyclical nature. She describes the basic process of risk regulation as a progression that includes:

[A] determination of both [the regulator's] objectives and its risk appetite; an assessment of the hazards or adverse events occurring within regulated firms and the regulatory environment which relate to the ability of the regulator to achieve its objectives, their probability of occurring, and the nature of their likely impact; and the assigning of scores or rankings to regulated firms on the basis of these assessments. ${ }^{59}$

These steps are followed by evaluation and feedback to ensure the process is working properly and is up-to-date. This five-step progression can be visualized as follows:

www.thestar.com/news/gta/2016/06/14/rude-lawyer-joseph-groia-loses-appeal-on-incivilityconviction.html $>$. See also Adam Dodek, "An Education and Apprenticeship in Civility: Correspondent's Report from Canada" (2011) 14:2 Leg Ethics 239.

57 See Devlin \& Hefferman, supra note 8 ("it is just too convenient that the public interest in accessing legal services should be presumed to dovetail with the professional interest in providing such services" at 190).

$58 \quad$ Ibid.

$59 \quad$ Black, "Role of Risk," supra note 19 at 331. 


\section{Diagram 1: Idealized Risk Policy Progression ${ }^{60}$}

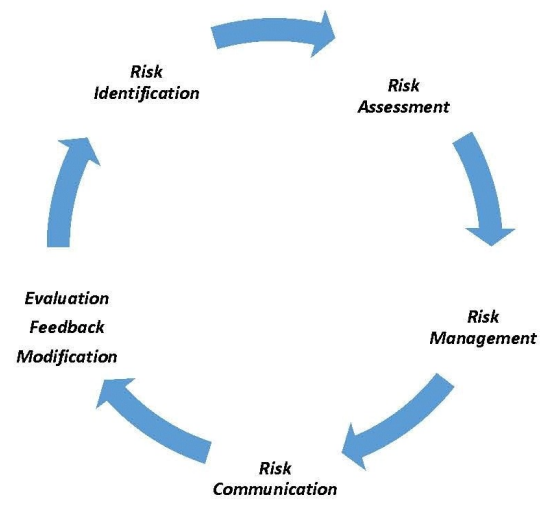

While there is some overlap between the stages, Black's idealized framework is useful for examining the steps of a risk-based regulatory regime in greater detail. We believe this framework is particularly useful because it imposes discipline on the regulatory process by requiring a connection to the objectives at every stage. We examine each stage in turn below.

\section{A. Risk IDENTIFICATION: ORgANIZATIONAL OBJECTIVES AND ASSOCIATED RISKS}

Our starting point in Black's five part cycle of risk regulation is risk identification. At this stage, the regulator must identify the risks that the regulatory regime seeks to avoid. In order to identify risks, each regulatory regime needs to articulate objectives that serve as the measuring stick for risk. The more developed the risk regulation system, the more explicit the articulation of the regulator's priorities. Advanced risk regulators have very clear statements of priorities for their organizations.

One example of a clear purpose statement comes from the Solicitor Regulation Authority (SRA), the regulator for solicitors in England and Wales. The SRA is the largest of the UK's legal regulators with over 170,000 professionals under its jurisdiction. ${ }^{61}$ The entire regulatory system has clear objectives, set for the SRA by the government in the Legal Services Act 2007, which commits the regulatory regime to:

a) protecting and promoting the public interest;

b) supporting the constitutional principle of the rule of law;

c) improving access to justice;

d) protecting and promoting the interests of consumers;

e) promoting competition in the provision of services within subsection (2); regulated-community-statistics.page $>$. For a list of all approved regulators in England and Wales see online: Legal Services Board <www.legalservicesboard.org.uk/can_we_help/approved_regulators/>. 
f) encouraging an independent, strong, diverse and effective legal profession;

g) increasing public understanding of the citizen's legal rights and duties;

h) promoting and maintaining adherence to the professional principles. ${ }^{62}$

The SRA has translated these eight objectives into four regulatory "outcomes" that it strives to achieve:

1. The public interest is protected by ensuring that legal services are delivered ethically and the public have confidence in the legal system.

2. The market for legal services is competitive and diverse, and operates in the interests of consumers.

3. Consumers can access the services they need, receive a proper service and are treated fairly.

4. Regulation is effective, efficient and meets the principles of better regulation. ${ }^{63}$

Not all regulators will have sufficiently clear and detailed objectives from legislation and will need to set their own objectives, often in a strategic plan or a statement of priorities. ${ }^{64}$ Once the regulator's objectives have been elaborated, risk can be measured in terms of not meeting those objectives. The SRA periodically publishes a document entitled Risk Outlook, detailing the most significant present, emerging, and potential risks to meeting their objectives. The 2016-2017 Risk Outlook, published in July 2016, provides information on the seven greatest threats to the SRA's objectives:

- $\quad$ Lack of access to legal services

- Standards of service

- Investment schemes

- Information security

- $\quad$ Protecting client money

- Independence and integrity

- Money laundering

- $\quad$ Lack of diversity in the profession ${ }^{65}$

Risk regulation requires that the risk to be controlled have a rational connection to the regime's objectives. In Ontario, scholars have long argued that the Law Society of Ontario has been particularly concerned with certain types of risks or behaviours at the expense of others, ${ }^{66}$ especially concentrating on financial wrongdoing and failure to respond to the Law Society. ${ }^{67}$ Under risk regulation, the Law Society might still be able to focus on these forms

Legal Services Act 2007 (UK), c 29, s 1(1). The order of the objectives does not indicate a hierarchy. The "professional principles" referred to in section 1(h) are defined in section 1(3). See also Terry, Mark \& Gordon, supra note 37 at 2697. SRA, "Regulatory Risk Framework" (March 2014) at 4, online: <www.sra.org.uk/risk/risk-framework. page $>$.

See e.g. Nova Scotia Barristers' Society, "NSBS Regulatory Objectives,” online: <www.nsbs.org/nsbsregulatory-objectives>, which builds on that province's Legal Profession Act, SNS 2004, c 28, as amended by SNS 2010, c 56.

65 SRA, "Risk Outlook 2017/18” (25 July 2017), online: <www.sra.org.uk/risk/outlook/risk-outlook-20172018.page>.

66 Arthurs, "Dead Parrot," supra note 8; Alice Woolley, "Regulation in Practice: The 'Ethical Economy' of Lawyer Regulation in Canada and a Case Study of Lawyer Deviance" (2012) 15:2 Legal Ethics 243. See also Trebilcock, "Regulating Competence," supra note 1 at 455; Trebilcock, "Regulating the Market," supra note 35 at 225.

67 Harry W Arthurs, "Why Canadian Law Schools Do Not Teach Legal Ethics" in Kim Economides, ed, Ethical Challenges to Legal Education and Conduct (Oxford: Hart Publishing, 1997) 112. 
of risk, but there would be a clearly articulated public rationale as to why they were prioritizing these risks as opposed to others. Identifying objectives at the beginning of the process keeps regulators focused on what matters most.

\section{B. Risk Assessment: Collect and Process Data}

Risk regulation is a data-intensive exercise. Once objectives and risks have been identified and prioritized, risk assessment must be done on an ongoing basis to determine risks as they arise. This requires gathering and processing a significant amount of data.

The more thorough the data gathering, the more confident a regulator can be that it has located all risks. Data should come from a variety of sources. ${ }^{68}$ Data can be gathered from the regulated individuals through registration requirements for new members and via annual reporting requirements for existing members.

Complaints from clients are a valuable source of information, and one that most regulators are already accustomed to handling. For example, in New South Wales, both the Office of the Legal Services Commissioner and the Law Society of New South Wales handle complaints from clients. The Law Society aggregates all complaint data to create a detailed picture of each firm, including the firm's history and the employment history of its lawyers. ${ }^{69}$

Other sources can also be informative. The General Medical Council, the UK regulator for the 250,000 doctors in England, Scotland, Wales, and Northern Ireland, collects data from medical residents through annual surveys. ${ }^{70}$ Previous surveys have posed the question: "Do you have any concerns about patient safety at your [workplace]?",71 The General Medical Council found this question useful for locating areas of malpractice, as well as for signalling to young doctors that reporting their concerns is a part of professionalism. ${ }^{72}$

As demonstrated by the above examples, robust data collection will include both qualitative and quantitative information. In New South Wales, the Office of the Legal Services Commissioner has a system for collecting both types of data. The Commissioner's risk assessment system allows staff to input subjective assessments arising from interaction with regulated individuals. This might include comments about rudeness, known substance abuse issues or financial issues, or other observations that may impact a lawyer's practice. ${ }^{73}$ Subjective assessments could add insight into how multiple risk factors interact with each other - for example a high rate of turnover at a large firm with many young lawyers will not be as worrisome as high turnover in a small firm with a history of complaints. Firm

See also Trebilcock, "Regulating Competence," supra note 1 at 456-57; Trebilcock, "Regulating the Market," supra note 35 at 226.

Email from Jim Milne, Acting Commissioner, NSW Office of the Legal Services Commissioner (4 June 2014).

General Medical Council, The State of Medical Education And Practice In The UK: 2013 (London: GMC, 2013) ch 1 at 17, online: <www.gmc-uk.org/20131004_Chapter_1_SoMEP.pdf_53706030.pdf>. About 16,000 of these are inactive.

Ibid, ch 2 at 57.

This question was included in the 2012 and 2013 questionnaires (ibid).

Email from Jim Milne, supra note 69. 
culture is another difficult-to-measure variable that has a large impact on behaviour. ${ }^{74}$ Law societies might similarly consider surveying law students, articling students, and staff in regards to concerns such as those outlined above. ${ }^{75} \mathrm{We}$ suspect that such sources would provide an insightful source of relevant information for legal regulators.

Another option for data collection is self-assessment. In New South Wales, a designated compliance officer at each ILP was required to complete a self-assessment form to evaluate their management systems upon incorporation. The compliance officer had to declare the ILP fully compliant, compliant, partially compliant, or non-compliant with multiple benchmarks. ${ }^{76}$ One study of the self-assessment process found it very successful in improving standards of practice and reducing complaints. ${ }^{77}$ Forcing someone to answer questions about their practice helps him or her recognize deficiencies that may have otherwise gone unnoticed. The added step of adding a negative label such as "partially compliant" or "non-compliant" might shame firms into making improvements. Selfassessments are no longer required in New South Wales, ${ }^{78}$ but a similar requirement continues in Queensland. ${ }^{79}$ The Nova Scotia Barristers' Society also launched a pilot selfassessment project in fall $2016 .{ }^{80}$

Several Canadian medical colleges have also found self-assessments useful for physicians and surgeons. Medical colleges in Alberta, Manitoba, Nova Scotia, Ontario, Saskatchewan, Newfoundland, and Quebec use self-assessments either in general screening, for physicians at risk, or during individual reviews. ${ }^{81}$ According to Brian Salte, Associate Registrar of the College of Physicians and Surgeons of Saskatchewan, the medical profession has generally

Dodek, "Regulating Law Firms," supra note 42 at 388-93; Arthurs, "Dead Parrot," supra note 8; Lynn Mather, "How and Why Do Lawyers Misbehave? Lawyers, Discipline and Collegial Control" in Scott L Cummings, ed, The Paradox of Professionalism: Lawyers and the Possibility of Justice (Cambridge: Cambridge University Press, 2011); Ronald J Daniels, "The Law Firm as an Efficient Community" (1992) 37:3 McGill LJ 801. The UK's Financial Conduct Authority believes that firm culture is also a key variable for sellers of financial products. They have found that most instances of wrongdoing are linked to a failure of culture. See the FCA, "Financial Conduct Authority's Approach to Supervision Event" (20 March 2014), online: YouTube <www.youtube.com/watch?v=2cDDBaEXcJQ $>$ at 00h:18m:00s-00h:19m:15s (Clive Adamson, Director of Supervision).

75 We acknowledge that this would likely have to be connected to regulation of law firms. As discussed in note 5 , above, some legal regulators in Canada are actively considering regulating law firms.

Salyzyn, "What if We Didn't Wait?," supra note 42 at 526-28.

The study found that 71 percent of respondents "revised" firm policies after completing the selfassessment: Christine Parker, Tahlia Gordon \& Steve Mark, "Regulating Law Firm Ethics Management: An Empirical Assessment of an Innovation in Regulation of the Legal Profession in New South Wales" (2010) 37:3 JL \& Soc'y 466. See also Susan Fortney \& Tahlia Gordon, “Adopting Law Firm Management Systems to Survive and Thrive: A Study of the Australian Approach to Management-Based Regulation" (2013) 10:1 U St Thomas LJ 152; Salyzyn, "What if We Didn't Wait?," supra note 42 at 528-29.

78 Office of the Legal Services Commissioner, "Practice Management," online: <www.olsc.nsw. gov.au/Pages/lsc_practice_management/lsc_practice_management.aspx $>$; Email from Glenda Carry, Regulatory Compliance Solicitor at the Law Society of New South Wales (25 August 2016).

79 Legal Services Commission, "Self Assessment Audits," online: <www.lsc.qld.gov.au/compliance/ compliance-audits/self-assessment-audits $>$.

80 Nova Scotia Barristers' Society, “MSELP Self-Assessment Pilot Project,” online: <www.nsbs.org/ mselp-self-assessment-pilot-project $>$.

81 See a comparative chart of Canadian doctor assessment methods at Association of Faculties of Medicine of Canada, A Pan-Canadian Inventory of Physician Assessment, Enhancement, and Remediation Activities (2012) at 10-13, online: <www.bcsc.bc.ca/uploadedFiles/For_Registrants/Compliance Deficiency Chart.pdf?t=1404919132084>. 
recognized that mandatory self-reflection is the most effective way to change physician behaviour. $^{82}$

Compiling different types of data from multiple sources is very important. Putting all the data together reveals the patterns that form a key part of risk regulation. Robust data can track patterns of behaviour over time, revealing recidivism. It can expose links between different risk factors. It can also track the impact of new policies, technologies, or regulations. The Queensland Legal Services Commission examines their complaints data for worrying trends about individuals or firms. Where found, the Commission will send the firm or person a "risk alert" telling them of the problem, advising them of the nature of the complaints, and inviting them to review their practices to proactively deal with any shortcomings. ${ }^{83}$

However, expectations regarding data collection vary between industries. For example, doctors are accustomed to providing large amounts of information to their regulators. ${ }^{84} \mathrm{In}$ addition, there is a "robust expectation" within the profession that doctors will report any concerns they have regarding their colleagues, ${ }^{85}$ as well as legal requirements to report certain concerns. ${ }^{86}$

We recognize that in Canada, lawyers have become accustomed to minimally invasive regulation. In most jurisdictions, annual reporting requirements are not cumbersome. While continuing professional development is mandatory, obligations are minimal and very flexible (yet lawyers groan incessantly about them and have unsuccessfully challenged them ${ }^{87}$ ). Lawyers may face cyclical audits of their trust accounts but otherwise the average lawyer is unlikely to hear from the law society unless there is a complaint against him or her. Moreover, if there is a "robust expectation" in medicine that colleagues will report any concerns that they have about their co-workers, the opposite is true in law. ${ }^{88}$ The cruel fact is that Facebook and Google have more information about most lawyers in Canada than their regulators do. It will require a culture change for regulators to accustom lawyers to providing more information about their practices than they currently do.

There is also a concern that extensive data collection disproportionately burdens small and solo practitioners. A sole practitioner would have to respond to data collection requests

Brian Salte, "Quality Assurance and the Medical Profession," (April 2014) Remarks to Federation of Law Societies Council Meeting at 00h:06m:50s [on file with authors].

Legal Services Commission, 2012-2013 Annual Report at 46-47, online: <www.lsc.qld.gov.au/_data/ assets/pdf file/0014/216104/Legal-Services-Commission-2012-13-Annual-report.pdf $>$; Legal Services Commission, "Effective Regulation: Our Strategic and Performance Plans 2014-2016" (1 July 2014) at 8 .

Salte, supra note 82 .

Ibid at 00h:04m:20s. In Saskatchewan, for example, the College of Physicians and Surgeons of Saskatchewan Code of Ethics requires physicians to report colleagues who have unprofessional behaviour, who practice below an acceptable standard, or who are affected by a chemical dependency or medical disability (College of Physicians and Surgeons of Saskatchewan, Regulatory Bylaws (Saskatoon: CPSS, 2014) s 7.1(48)).

Health Professions Act, RSBC 1996, c 183, s 32.2. In Ontario, health facility operators are required to report incapacity and incompetence: Health Professions Procedural Code, being Schedule 2 to the Regulated Health Professions Act, 1991, SO 1991, c 18.

See Green v Law Society of Manitoba, 2017 SCC 20, [2017] 1 SCR 360.

See e.g. Ronalda Nordal, "Duty to Report Incompetence/Misconduct," Law Society of Saskatchewan Benchers' Digest 27:2 (May 2014) 1, online: <https://www.lawsociety.sk.ca/media/84501/bd2014may. pdf $>$. 
regarding him or herself as an individual, and on behalf of the firm. Yet small and solo practitioners often have little flexibility to forego billable hours for increased administrative work. Expanded data collection could be an annoyance that also eats into the bottom line of the profession's most precarious practitioners. A balance needs to be struck between collecting the information that risk regulation requires to function and avoiding an onerous burden, particularly an unequal one, on regulated professionals. ${ }^{89}$ Solutions will have to be tailored to meet the needs of each regulator.

Collected data must be analyzed before it can guide regulatory action. Various risk regulators have developed different ways of doing this. Importantly, data must be analyzed according to a standardized process that reflects the regulatory objectives. This can take many forms at different levels of sophistication.

A simple example comes from the Ontario Securities Commission (OSC). The information for OSC risk ratings comes mainly from a mandatory risk-assessment questionnaire periodically sent to firms. The most recent questionnaire was published in 2016 and collects information on a variety of topics depending on the firm's activities. ${ }^{90}$ In essence, the regulated firms are completing their own risk assessment. The OSC can look directly at those questionnaires for certain risk factors and tailor interventions accordingly. ${ }^{91}$

While most regulators do not reveal what risk factors they look for, some share this information publicly. In the UK, the General Medical Council conducts "performance assessments" on physicians of concern. Information that could trigger a performance assessment comes from many sources, including complaints, reporting by peers, selfreporting, or from information in the media. ${ }^{92}$ The Council looks for indications of the following risk factors:

a tendency to use inappropriate or out-dated techniques;

- a basic lack of knowledge/poor judgement;

- a lack of familiarity with basic clinical/administrative procedures;

- $\quad$ poor record keeping or failure to keep up-to-date records;

- $\quad$ inadequate practice arrangements;

- $\quad$ concerns over referral rates;

This is true in other industries as well. The Ontario Securities Commission is aware of its impact on the businesses it regulates and its priorities include reviewing "filing requirements to identify opportunities to cease collection of data that is not used, lightly used, or readily available elsewhere" (Notice of Statement of Priorities for Financial Year to End March 31, 2015, OSC Notice 11-770 (26 June 2014) at $7,9,13$.

90 Ontario Securities Commission, “2016 Risk Assessment Questionnaire: FAQ and User Guide,” online: $<$ www.osc.gov.on.ca/documents/en/Dealers/da_20160518 faq-2016-risk-assessment-questionnaire. pdf $>$. All previous versions of the questionnaire can be accessed at Ontario Securities Commission, "OSC Compliance Reviews," online: <www.osc.gov.on.ca/en/Dealers compliance-review index.htm> [OSC, "Compliance Reviews"].

91 The OSC does not publicly share their risk factors. OSC can take many actions to intervene where warranted, including ceasing trade orders, ordering the restatement or refilling of financial statements, imposing conditions on a registrant, or taking enforcement action in front of an independent administrative panel (Ontario Securities Commission, "Our Role," online: <www.osc.gov.on.ca/en/ About_our-role_index.htm>).

92 Email from Renay Taylor, General Medical Council (28 July 2014). 
- $\quad$ inadequate hygiene arrangements; [or]

- $\quad$ poor prescribing. ${ }^{93}$

Where these risk factors are found, the General Medical Council is more likely to undertake a performance assessment to check up on the doctor.

Other regulators have developed sophisticated scoring mechanisms that transform incoming information into standardized numerical scores. ${ }^{94}$ The Investment Industry Regulatory Organization of Canada (IIROC) regulates all investment dealer firms in Canada. IIROC engages in the most comprehensive risk-based regulation of any Canadian regulator, and uses quantitative risk scoring in three parallel compliance-based processes. ${ }^{95}$ In one of those processes, the business conduct department uses a risk assessment model to guide their supervision of firms' non-financial policies, procedures, and controls. The model requires classifying risk factors and risk minimizers, weighing them by category and combining them using a mathematical formula to produce a business risk score. That score is used to rate the firm's business risk in comparison to other investment dealers as low, moderate-low, moderate-high, or high. ${ }^{96}$

Similarly, the British Columbia Securities Commission (BCSC) operates multiple riskranking systems that use numerical scoring matrices. Its process for assessing individual applications is particularly interesting for its use of both quantitative and qualitative factors. Every year, the BCSC processes approximately 3,000 applications from individuals who wish to become registered securities professionals. Formerly, the BCSC conducted in-depth reviews of every applicant, even though only 3 percent of applications revealed information that required follow-up. Using a body of old applications, the BCSC searched for correlations between fields on the application form and the 3 per cent of applications that revealed concerns. They also conducted a textual analysis of the responses to the essay-style questions in the application form for similar correlations. ${ }^{97}$ With this information, they built a risk assessment model that identifies 35 variables and key words that correlate with applications of concern. A computer program uses the model to generate a risk score of 1-100 for each new application. In addition to the numerical risk score, BCSC staff can also add information that does not fit into the mathematical model. This could include such factors as whether the

General Medical Council, "Doctors Under Investigation — Performance Assessments," online: <www. gmc-uk.org/concerns/doctors_under_investigation/performance_assessments.asp >.

The SRA also has a detailed scoring process for rating the risk posed by events. For details see: SRA, "Incoming Reports - Risk Assessment Methodology," online: <www.sra.org.uk/risk/reportsassessment-method.page $>$ [SRA, "Incoming Reports"]. The Financial Conduct Authority, the regulator for the UK financial services industry, has two methodologies to assess risks either from a "firms approach" or from a "thematic approach."

The three processes are financial operations, trading practice, and business conduct (conversation with Warren Funt, Vice-President, Western Canada, IIROC (7 July 2014)).

The formula is: Trading Risk Score - $[\mathbf{4 0 \%}$ of Risk Control Score] = Risk Score. First, the "trading risk score" is calculated by measuring 17 specific risks. These 17 risks are divided into three types and weighted differently: Inherent risks $35 \%$; external factors $15 \%$; and internal factors $50 \%$. Next, the "risk control" score is calculated by measuring seven types of "risk controls." These are measures that the firm uses to mitigate or reduce its business risk. The risk control score is weighted at $40 \%$ to recognize that, no matter how strong the firm's internal controls, risk can never be completely controlled. Finally, the reduced risk control score is subtracted from the trading risk score to produce the total score (IIROC, "Business Conduct," online: <www.iiroc.ca/industry/industrycompliance/Pages/Business-Conduct. $\operatorname{aspx}>$ ).

Applicants apply to the national Canadian Securities Association and are then processed by their provincial regulators. The national forms were tested for correlations and key words (phone call with Christina Wolf, Chief Economist at BCSC (15 July 2014)). 
individual has previously been registered and had problems with discipline, or if the individual has recently filed for bankruptcy. ${ }^{98}$

Risk scoring matrices are also being used in the legal profession. In the UK, the Solicitors Regulation Authority uses risk matrices to assign scores to each licensed law firm or alternative business structure. They also use a parallel risk scoring process to assess events. The event risk scoring process involves both quantitative and qualitative variables, based on the following formula: Event score x Impact Score x Source Credibility x Strength of Evidence $=$ Event Risk $^{99}$

First, each allegation is assigned one of around 180 different event categorizations from an Event Risk Classification table. Each entry in the table comes with an event score from one to ten representing the seriousness of the event. For example, level ten risks include being a perpetrator or facilitator of money laundering, misappropriation of client money, or an unqualified person holding out as a solicitor. ${ }^{100}$

Second, staff assign each event an impact score ranging from one (Minor) to five (Catastrophic). The impact score considers the consequences of the alleged event, assuming the facts of the allegation to be true. ${ }^{101}$ The score is determined by four variables:

- the number of people affected;

- the financial implications;

- the effect on public confidence; and

- the relative vulnerability of the people affected. ${ }^{102}$

Finally, staff make a subjective analysis of the credibility of the source and the quality of the intelligence or supporting evidence. This establishes the probability that the report is an accurate reflection of real events. ${ }^{103}$ Risk scores are a starting point only and can be further influenced by the staff's personal knowledge of a situation. For example, there is no separate part of the event score to represent history. However, in practice, "assessors sometimes use their override option to inflate the risk assessment (which is all auditable to ensure bias is not behind it) where there is something obvious in the current or recent life of the firm that is known to them and would make the pure event score incorrect." 104 The total event score is rated as red, amber, or green.

Here in Canada, the Nova Scotia Barristers' Society has started developing its own risk matrix. Like the SRA's model, the Barristers' Society has started with a risk index to classify risks by type. Then, using the impact risk matrix, risks can be scored for impact and

See $i b i d$ for an incomplete list. For a comprehensive table of risk scoring categories, the SRA must be contacted by email.

101 Ibid; Email from Andrew Garbutt (30 May 2014)

102 SRA, "Incoming Reports," ibid at subheading "Process - Step by Step"; SRA, "How the SRA uses the Risk Framework to Deliver Risk-Based Outcomes-Focused Regulation" (15 May 2013), online: $<$ www.sra.org.uk/sra/news/events/webinar-2013-05-15-risk-framework.page> at 00h:22m:30s [SRA, "Risk Framework Webinar"].

SRA, "Risk Framework Webinar," ibid at 00h:22m:45s. This third factor is also called the Probability Score in some documents.

104

Email from Andrew Garbutt (30 May 2014). 
likelihood, resulting in an overall score. The model is still in development, but is part of a wider regulatory overhaul that makes the Nova Scotia Barristers' Society the leading Canadian legal regulator in terms of risk regulation.

\section{RiSK MANAGEMENT: INTERVENE ACCORDINGLY}

Although organizations such as IIROC have put much work into their scoring matrices, we are not arguing for slavish adherence to their results. Using a risk scoring matrix allows organizations to analyze risk in a standardized way. It allows organizations to compare and prioritize risks. But once those risks are located, organizations still have to decide where and how to intervene.

For example, an organization could undertake only risk-based interventions. Or risk-based interventions could occur side-by-side with random check-ups and program-specific intervention. Compliance audits are a tool frequently used by risk regulators. ${ }^{105}$ Risk regulation means these audits can be focused on statistically high-risk areas. ${ }^{106}$ For example, the OSC chooses where to conduct compliance reviews of firms in several ways. ${ }^{107}$ The main selection method is risk-based. ${ }^{108}$ In addition, firms could be selected for review: in a "sweep" in which the OSC reviews firms in relation to a particular issue of concern; a mandatory assessment for all new firms; subsequent to a complaint from a client or another regulator; and finally, firms could be randomly selected for a compliance review. ${ }^{109}$

Regulators must also choose how to intervene. Most regulators have a spectrum of enforcement tools, with formal discipline comprising only a part of that spectrum. Here in Canada, the Law Society of Alberta has recently launched an "Early Intervention Intake System." Anyone can submit information of concern about a lawyer, by phone or online. That incoming information is then triaged by an intake specialist based on risk of imminent harm to the public or the profession and directed to the appropriate place. Among the options are specialized counsel who can assist in attempting to reach an informal resolution of the problem and an early intervention department which offers programs and resources to lawyers. If more intense measures are called for, the file can be referred to the discipline department for further investigation. ${ }^{110}$

Among the organizations discussed in this article, the following use risk statistics or risk factors to determine where to conduct pro-active compliance checks on their regulated professionals: the Office of the Legal Services Commissioner in New South Wales; the Legal Services Commission of Queensland; the IIROC; the Ontario Securities Commission; the BC Securities Commission; the Financial Conduct Authority (UK); and the General Medical Council (UK). Trebilcock, "Regulating Competence," supra note 1 at 457, 459; Trebilcock, "Regulating the Market," supra note 35 at 226-27, 231-32.

107 The OSC reviews advisers, exempt market dealers, scholarship plan dealers, and investment fund managers. Other organizations review other types of dealers. See: OSC, "Compliance Reviews," supra note 90.

108 See James Langton, “OSC Issues 2014 Risk Assessment Questionnaire,” Investment Executive (10 June 2014), online <www.investmentexecutive.com/-/osc-issues-2014-risk-assessment-questionnaire>.

109 OSC, "Compliance Reviews," supra note 90

110 Law Society of Alberta, "Providing Information Concerning a Lawyer," online: <https://www.law society.ab.ca/public/providing-information-concerning-a-lawyer>. See also Law Society of Alberta, "Law Society Launches Early Intervention," e-Bulletin (9 November 2016) [on file with authors]. For reasons that we identify in supra note 29 and accompanying text, we express skepticism about the propriety of "harm to the profession" as a valid regulatory objective. 
Continuing with the SRA example, much of their intervention activity is based around helping firms optimize their risk management and other practices before risks escalate. The SRA has a spectrum of non-disciplinary tools to use if intervention is necessary. These include placing a practitioner under supervision or sending information to the regulated community to raise awareness or inform of best practices. ${ }^{111}$ Disciplinary sanctions may result from the risk assessment process where warranted. ${ }^{112}$ The SRA may give a regulated person a limited selection of (lighter) disciplinary punishments, such as a written rebuke or a monetary penalty. Severe cases are referred to the independent Solicitors Disciplinary Tribunal, which is able to dispense punishments including suspension or disbarment. ${ }^{113}$

The SRA provides just one example of a toolbox of regulatory interventions. Different risks will call for different interventions. The benefit of risk regulation is that it brings the differences in risk into brighter focus so that the right tool for the job can be employed.

\section{RISK COMMUNICATION: SHARE INFORMATION WHERE NECESSARY}

Risk regulation requires significant information sharing between different branches of regulators or with other agencies. Sharing information is important for three reasons. First, to ensure that all relevant information is collected and fed into the risk assessment process. ${ }^{114}$ Information including complaints, financial information, and insurance claims may be critical to the risk assessment process. Sometimes, different agencies or parts of agencies will be responsible for collecting different forms of data. Regulators should have policies to enable data sharing with those conducting the risk assessments. For example, in England and Wales, the SRA does not deal with consumer-oriented complaints. These are collected by the Legal Ombudsman. The Legal Ombudsman informs the SRA of all complaints made to it, so that the SRA can incorporate them into risk profiles. ${ }^{115}$ Indeed, the UK's Legal Services Act mandates that all reports of misconduct must be referred to the approved regulators. ${ }^{116}$

Second, information sharing is necessary to ensure that appropriate action is taken when risks are located. For example, risk regulators may continue to approach discipline as a separate internal process. They must have policies in place to govern how and when information can be shared between the staff conducting risk assessments and the staff responsible for the discipline. For IIROC, the file is simply transferred from compliance to enforcement when the disciplinary process is triggered. ${ }^{117}$ In contrast, legislation or bylaws seriously circumscribe the information that can be transferred from compliance to enforcement at the College of Physicians and Surgeons of British Columbia. Essentially, only the fact that there is basis for a complaint against a doctor can be communicated to enforcement, and not any details of that complaint. The enforcement unit then conducts their

For more on the other ways the SRA can assist with compliance, see: SRA, "SRA Enforcement Strategy," online: <www.sra.org.uk/sra/strategy/sub-strategies/sra-enforcement-strategy.page>. Phone call with SRA helpline (22 May 2014).

The tribunal was established and empowered by the Solicitors Act 1974 (UK), c 47, s 46.

Trebilcock, "Regulating Competence," supra note 1 at 456-57; Trebilcock, "Regulating the Market," supra note 35 at $226-27$.

Email from Andrew Garbutt (30 May 2014). The SRA also shares information with the Legal Ombudsman.

Supra note 62, s 143.

Conversation with Warren Funt, Vice-President, Western Canada, IIROC (7 July 2014). 
own investigation. This is a "one-way firewall": enforcement cannot see any of the compliance reports, but compliance can see the complaints history of the doctor. ${ }^{118}$ The OSC charts a middle ground. The compliance unit will refer serious complaints to enforcement, but will not transfer any portions of the file involving interviews of the registrant. ${ }^{119}$

Thirdly, information sharing is necessary to design and update the risk framework. This includes the objectives and risks identified in the first stage of Black's five-part risk cycle, as well as any risk matrix used at the risk assessment stage. The Nova Scotia Barristers' Society began its foray into risk regulation with risk-based auditing of trust accounts after developing a profile of lawyers who stole money from client trust accounts in the 1990s. That risk profile was updated based on thefts that occurred in the $2000 \mathrm{~s} .{ }^{120}$ By sharing information between internal departments, the Barristers' Society was able to track the most serious risks as they changed and update their risk assessment process accordingly.

Risk communication can also include communicating risk to regulated professionals. For example, IIROC issues firms an "early warning" if their financial indicators reach a certain level. This gives firms the chance to improve their practices and avoid suspension. ${ }^{121}$ Most organizations do not share individualized risk scores with their regulated population. ${ }^{122}$ However, risk can also be communicated on a more general level. For example, the OSC periodically sends notifications about common deficiencies (and how to avoid them) to all registrants.

\section{E. Evaluation, Feedback, AND MODIFICATION OF RISK CYCLE}

The final stage in Black's risk cycle is evaluation, feedback, and modification. The world of risk is a dynamic one. Regulated populations respond to regulatory interventions and policies. New technologies and ways of doing business lead to new risks. Risk regulators have to stay current.

Luckily, the data collection inherent in risk regulation facilitates modification. Emerging trends in changing risks can be spotted early and addressed. Where a formal risk-scoring matrix is used, that matrix can easily be tweaked to reflect changes in risks or priorities. The SRA's Risk Outlook document is an instructive example of how risks in the profession change over time. In the 2013/2014 edition, financial difficulty was identified as a top risk. The concern was that the economic crisis would cause some firms to close abruptly without

118 Email from Galt Wilson, Deputy Registrar, Complaints and Practice Investigations, College of Physicians and Surgeons of British Columbia (5 July 2014).

119 The OSC never includes material relating to voluntary interviews with registrants because of concerns of administrative fairness arising out of the Supreme Court's decision in $R v$ Jarvis, 2002 SCC 73, [2002] 3 SCR 757 .

120 Conversation with Victoria Rees (30 April 2014).

121 IIROC, "Financial \& Operations Compliance," online: <www.iiroc.ca/industry/industrycompliance/ Pages/Financial-Operations.aspx $>$.

122 The SRA rates all regulated firms; however, it does not share each firm's score with it, saying that as scores fluctuate, revealing the score at any particular time is not informative. SRA, "Risk Q \& A," online: <www.sra.org.uk/risk/risk-questions-and-answers.page>. The Colleges of Physicians and Surgeons in Saskatchewan and British Columbia give their professionals feedback following audits so they can understand how they have scored relative to their peer group. See Practice Enhancement Program for Saskatchewan Doctors, "Assessment Process," online: <www.pepsask.ca/assessment/ assessment-process $>$. 
adequately closing client files. Data also indicated that firms in financial difficulty are more prone to criminal misuse of money. Now that the worst of the global financial crisis is past, the 2017/18 edition of Risk Outlook no longer includes that risk; new risks including information security are now on the list. ${ }^{123}$

In addition, the goals set at the first stage of the process can now serve as a measuring stick to evaluate the regulator's performance. This is true for the regulator's self-assessment. Ideally, this should also be true for the regulated population and for external third parties. The regulator's goals should be public, allowing others to evaluate for themselves whether the regulator is performing well. However, beyond this, the level of evaluation possible will depend on how much information the regulator makes public. As discussed above, some regulators disclose their risk factors, or even their numerical risk scoring matrices, which would allow third parties to conduct in-depth audits of how the system is working. Many others do not. However, as long as the regulator's goals are stated publicly, risk regulation brings a valuable measure of accountability into the regulatory cycle.

Keeping regulation goal-oriented creates efficiencies as well as providing accountability. By focusing on high risk actors or actions, regulators are focusing their efforts where they are most needed. Canadian legal regulators have finite budgets. They have an interest in achieving as much as possible within their constraints. Likewise, the regulated population, which pays a substantial portion of their regulator's budgets, has an interest in seeing their money used effectively. In addition, regulation can be a burden - for example, compliance takes time away from seeing clients and billable work. The whole system would benefit from redistributing the burden of regulation to the high-risk areas where it is needed most. ${ }^{124}$ Attendant cost savings could free up regulatory resources for other matters further down the priority list, or be passed back to the regulated population.

\section{CONCLUSION}

Adopting risk regulation will necessitate a significant transformation for legal services regulation, involving changes for both the regulators and the regulated. These changes are both cultural and operational and nowhere are they bigger than regarding data analysis. For regulators, it will involve a fundamental change in how they do business; a shift from reactive to proactive regulation. It will involve restructuring and reallocation of resources. ${ }^{125}$ This is never an easy task in large, mature organizations. For the regulated, this means a big

SRA, "Risk Outlook 2017/18," supra note 65.

As the IIROC says on its website, risk regulation allows it to "re-allocate resources to firms that have a higher than average potential to cause risk to the public, thereby enhancing the quality of regulation while minimizing unnecessary regulatory burden on firms posing little or no risk" (IIROC, "Risk Trend Report," online: <www.iiroc.ca/industry/industry compliance/Pages/Risk-Trend-Report.aspx>).

While risk regulation definitely requires a reallocation of resources, it may or may not require increased resources. In 2015, Canada's largest legal regulator, the Law Society of Ontario had expenditures of $\$ 1,593$ per regulated professional. Meanwhile, the SRA in England and Wales, a sophisticated risk regulator, spent $£ 413$ per regulated professional (approximately CDN \$715) in their 2015-2016 fiscal year. This may be illustrative of economies of scale: the Law Society of Ontario governs 56,675 professionals and the SRA 174,095 (Law Society of Ontario, "2015 Annual Report Data," online: $<$ www.annualreport.lsuc.on.ca/2015/en/annual-report-data.html\#LawyersGenderTotal $>$ Law Society of Ontario, 2015 Financial Statements (2016) at 3-4, online: <www.annualreport.lsuc.on.ca/2015/en/ financial-statements/LSUC 2015 Financial Statements.pdf $>$; SRA, "Regulated Population Statistics," online: <www.sra.org.uk/sra/how-we-work/reports/data/population_solicitors.page>; SRA, "SRA Business Plan," online: <www.sra.org.uk/sra/strategy/business-plan/sra-business-plan-2015-2016.page\# heading_toc_j_8 $>$. 
change from the laissez faire regulation many are used to. Very little is demanded of lawyers (and notaries in Quebec) from their regulators: payment of an annual fee and insurance, the completion of an annual report, and a small number of continuing professional development hours. Like doctors, lawyers would have to adjust to providing far more information to their regulators about themselves and their activities.

Likewise, regulators will have to adapt to seeking, processing, analyzing, and using that data. Appropriate privacy policies will have to be implemented to deal with the larger volumes of personal information. Regulators will have to hire people with new skills in statistics, data analytics, and risk assessment. Finding people with the necessary combination of legal and IT skills may be challenging. As the Canadian Bar Association's Futures Report points out, new jobs are already emerging at the intersection of law and technology. ${ }^{126}$ Regulators will need to harness that skill set to process the data they collect. Legal educators could play a role in developing candidates with such expertise.

Another challenge to risk regulation will be attaining a consensus on the definition of the public interest. As discussed above, the public interest is a contested concept. Although each regulator must develop its own definitions, the regulated populations are diverse. Different segments of the legal profession have different priorities, as do consumers of legal services. We have offered our thoughts on the public interest in this article, but a larger conversation needs to take place. To work, risk regulation requires goals framed in terms of risk. While these goals can be dynamic and ever-changing, some level of definition is required to set the risk regulation cycle in motion.

Finally, it is important to situate risk regulation in the context of the greater change happening in the Canadian legal profession. In Canada, the Nova Scotia Barristers' Society has introduced some entity regulation. ${ }^{127}$ The British Columbia Law Society and a consortium of prairie regulators are considering it. ${ }^{128}$ The Law Society of Ontario is preparing for entity regulation. ${ }^{129}$ When it does fully arrive, the risk regulation cycle discussed above can apply to individuals or firms, or a combination of both. In the UK, the SRA has been using both risk regulation and entity regulation for years. Indeed, the two go well together. Information collection can be centralized at the firm level, and variables such as firm culture can be included in risk rating methodologies. Intervention activities such as audits can be focused on firms instead of individuals. Risk regulation is a flexible system that can be easily adapted to work with, or without, entity regulation.

We are under no illusions that risk regulation involves a paradigm shift in the way that law societies and lawyers have thought about and grown accustomed to regulation in Canada. The adoption of a risk paradigm has broader implications for the regulation of the legal profession and could impact the relationship between legal regulators and law schools, Canadian Bar Association, 2014) at 21-22.

127 Nova Scotia Barristers' Society, "Legal Services Regulation,” online: <www.nsbs.org/legal-servicesregulation>.

128 Law Society of British Columbia, "2015-2017 Strategic Plan,” online: <https://www.lawsociety.bc.ca/ docs/about/StrategicPlan_2015-17.pdf>; Law Societies, Innovating Regulation, supra note 5.

129 Law Society of Ontario, "Compliance-Based Entity Regulation," online: <www.lsuc.on.ca/betterpractices/>; Compliance-Based Entity Regulation Task Force, Report to Convocation, supra note 5. 
licensing standards, continuing professional development, the provision of legal services by non-lawyers, alternative business structures, and other subjects. These are all issues that will require their own detailed consideration.

Change is hard, but it is necessary. In this article, we have made the case that risk regulation is better than the command and control regulation that currently characterizes the Canadian legal profession. Risk regulation would make the regulation of the legal profession more transparent and accountable (by forcing transparent goal setting) and more effective and efficient (by linking action to risk). If we are correct in these assertions, the question shifts from why should legal regulators engage in risk regulation to why they are not doing so? We are not alone in asking this question. We are joined already by regulators including the Nova Scotia Barristers' Society and the SRA. We are encouraged by the increasingly loud conversation the Canadian legal profession is having about change - and hope that legal regulators will consider the value risk regulation could bring to their work. 
[this page is intentionally blank] 